\title{
Examining Gender Equity in Newspaper Coverage of West-Central Ohio High School Basketball Games
}

\author{
JOSEPH P. GREEN' ', The Ohio State University, Lima, Lima, OH; ASHLEY M. HOLTZAPPLE, Medical University of South Carolina, \\ Charleston, SC; LAUREN MCKINLEY, University of Cincinnati, Cincinnati, OH, USA
}

\begin{abstract}
We investigated the sports coverage of over 300 boys' and girls' high school basketball games between 2000 and 2010 by two west-central Ohio newspapers. Unlike previous investigations on media reports of high school sports, we restricted our sample to actual games and did not include feature articles about individual athletes, coaches, or booster clubs; and we determined article length by counting the number of words used in each article. We found that boys' games received two to three times the length of coverage of girls' games. Media coverage of girls' games was less likely to include a photograph and tended to begin lower on the sports page. We discuss the potential implications of ignoring girls' high school athletics within community media.
\end{abstract}

\section{INTRODUCTION}

With the passage of Title IX legislation in 1972 - requiring equal access to equipment, practice facilities and coaches of the same quality at the K-12 level, and scholarship money proportional to participation at the college level - the number of girls and women participating in sports in the United States has skyrocketed. At the global level, the Olympic Charter of the International Olympic Committee has championed sports participation by female athletes. After adding women's boxing to the 2012 Olympic Games in London, women competed in every sport at the Olympics (IOC 2014).

Parallel to the rise of female athletics worldwide, the sociology of sport has flourished, with numerousstudies concentrating on the growing commercialization of sport and the framing and identity of sports based on gender, race, class, and ability. Media is central to how sport is understood and provides a framework for highlighting social and cultural values regarding fitness, health, fairness, and competition. One of the founding figures within sports sociology, Lawrence Wenner, recently argued that "media influenced the doing and meaning of sport at virtually every level" and that "the 'story' of sport, the explanation of its meaning and importance, may be far more culturally significant than the mounting of sport or the results of competition" (Wenner 2015).

Most critical examinations of sports media have

${ }^{1}$ Address correspondence to Joseph P. Green, 430 Galvin Hall, 4240 Campus Dr., Lima, OH 45804. Email: Green.301@osu. edu been at the collegiate or professional level; however, there is growing interest in media coverage of high school sports (Hardin and Corrigan 2008; Pedersen 2002a). As one of only a handful of investigations examining potential gender bias in media coverage of interscholastic athletics at the secondary school level, we examined structural bias in the length of print media coverage of boys' and girls' basketball games across four seasons in two Ohio towns. To place our study and findings in context, we will briefly present some of the benefits of sports participation among young girls, highlight studies examining gender bias in sports media coverage at the high school and collegiate levels, discuss how sports are framed and understood by our society's construction of gender, and conclude by calling for more equitable media attention to girls' sports and young female athletes.

\section{Benefits of Sports Participation Among Girls}

There are a number of benefits - both at the personal and societal level - associated with girls' athletics. For example, sports participation is associated with enhanced self-esteem and greater self-confidence (Lopiano 2002; Women's Sports Foundation 2009). Adolescent athletes are less likely to smoke, have better nutritional habits (Taliaferro et al.2010), and are more likely to use seatbelts when riding in cars (Robinson et al. 2002). Girls who participate in sports have higher graduation rates and lower unintended pregnancy rates (Hall 1998). Furthermore, at the high school level, girl athletes appear to be less vulnerable to disordered eating patterns and more satisfied with their bodies relative to non-athletes (Smolak et al. 2000). 
Today, more girls are engaging in sports at earlier ages and are learning firsthand the important link between fitness and lifelong health. Sports-minded youth are more likely to remain active in adulthood compared with those who do not participate in youth athletics (Keathley et al. 2013). Sustained physical activity leads to life-long benefits in health and wellbeing, including lowering the risk of type2 diabetes, breast cancer, obesity, and osteoporosis (Women's Sports Foundation 2009, 2013). Those who participate in sports learn discipline, teamwork, and persistence; develop character and are provided with opportunities for leadership, inter-racial connections, and community relations; and learn how to handle success and failure. Indeed, surveys of female executives of Fortune 500 companies found that more than 80 percent described themselves as "tomboys" growing up and attributed at least some of their professional success to their sports background (Bunker 1988; Women's Sports Foundation 2009). In addition to physical and psychological benefits such as greater emotional control and enhanced personal resiliency, sports participation is associated with better grades and a greater likelihood of attending college (Le Menestrel and Perkins 2007). Title IX has generated far more than a 30-40 percent rise in female participation rates in high school sports. Stevenson (2010) calculated that Title IX legislation was responsible for a 3.5 percent increase in college attendance, a two percent increase in the probability of obtaining a four-year college degree, and a 1.5 percent increase in the probability of securing a high skill job traditionally held by men.

There are some negative outcomes associated with sports participation as well. Not surprisingly, athletes, relative to their peers who are not in sports, are more likely to suffer injuries sustained during practice or competitions. High school athletes may be at increased risk to take performance-enhancing drugs and to use alcohol, especially boys (Dodge and Jaccard 2006; Taliaferro et al. 2010). In a survey of more than 36,000 eighth and 10th graders, Dever et al. (2013) reported higher alcohol use among eighth grade boys and girls who participated in sports. On the other hand, sports participation was associated with lower marijuana use among 10th grade female athletes. It is commonly believed that girls who participate in sports emphasizing thinness (e.g., dancers, runners, and gymnasts) may be at higher risk of disordered eating patterns (Bissell and Birchall 2008; Currie 2010). However, the evidence linking sports participation with negative outcomes is neither straightforward nor easily interpretable, likely varies by age and race and across different sports, and undoubtedly is mediated by personality, family history, and other risk factors (Smolak et. al 2000).

\section{Media Coverage of Sports by Gender}

Whereas the balance of evidence leans heavily in favor of girls participating in sports, media coverage of sporting events often varies as a function of gender. Given that athleticism and sports participation have historically been viewed as the purview of boys and men (Hardin 2005; Pedersen 2002a), it is perhaps not surprising that female athletes and women's sports have traditionally received far less media attention relative to male athletes and men's sports (Cooky et al. 2010). Sports media generally excludes women by granting them far less coverage than male athletes (Kian et al. 2008; Lopiano 2002). For instance, high school and collegiate female athletes received less than two percent of sports media coverage on major networks and were represented on ESPN Magazine covers less than four percent of the time (Women's Sports Foundation 2013). Similarly, Godoy-Pressland (2014) sampled Sunday editions of British print media over the course of two years and found that women received less than four percent of the overall sports coverage. In addition to disparities in coverage, newscast descriptions of sports often vary by gender. For example, whereas failure by a male athlete may be attributed to a lack of skill, failure by a female athlete is more commonly described as a lack of commitment (Eastman and Billings 2000).

Although substantive coverage of college sports is viewed as being less gender-biased than that of professional sports (Calia 1993), gender-based discrepancies in the amount of media coverage at the collegiate level are common. For example, Huffman et al. (2004) analyzed more than 400 print and broadcast sports stories from college media stations during a single month in 2000. They found that male sports got the majority of coverage, with 73 percent of print and 81 percent of broadcast stories focusing on male athletes. The authors reported that men playing college baseball received more than double the broadcast time or print space allotted to women playing college softball. Interestingly, whereas the authors reported that the quantity of news coverage of college athletics differed for men's and women's sports, the quality of coverage was consistent, at least within their sample of one newscast and one newspaper from each of 39 schools. When an article or broadcast featured a female 
athlete, Huffman et al. (2004) found that the length of the story, the likelihood of it including a photograph or quote, and the placement of the article was similar to featured stories of male athletes.

Whereas most critical examinations of media coverage of sports have been at the collegiate and professional levels, there is increased interest in the media coverage of high school sports. Hardin and Corrigan (2008), for example, challenged journalists, educators, and scholars to more closely scrutinize high school sports coverage at both the local and national levels, arguing that media coverage of high school sports reflects a host of important social and ethical issues. In what was arguably the first critical examination of media coverage of sports extended to the high school level, Pedersen (2002a) sampled all daily newspapers in the state of Florida published within a one-year timeframe and performed a content analysis of nearly 1,800 articles. Even after considering the gender breakdown within schools, participation rates, and the number of sports offered, Pedersen (2002a) found that high school girls' athletics were allotted fewer articles, articles of shorter length, and articles that were less prominently displayed within the layout of the newspaper. Across the entire sample of articles, female interscholastic athletics received slightly less than one-third of the sports coverage. In a separate study of 825 newspaper photographs of high school athletes, Pedersen (2002b) reported that female athletics was marginalized by fewer photographs, smaller sized pictures, and pictures of lower quality.

More recently, Whiteside and Rightler-McDaniels (2013) mined the U.S. NewsBank database to compare the length of news articles featuring boy and girl athletes playing high school basketball. Analyzing 459 articles from 121 newspapers across the southern region of the U.S., the authors reported that boys received more coverage overall (63 percent of articles featured stories about boys' basketball); however, the quality of the coverage was similar across stories featuring boys' and girls' basketball teams and players. Furthermore, the length of articles and their placement within the paper was similar for stories about individual boy and girl athletes as well as for stories about boys' and girls' teams. An important consideration of this study and those by Pedersen $(2002 a, 2002 b)$ is that the sample of articles was not restricted to actual game coverage. Instead, their samples included feature stories, advances, and follow up reports, leaving it unclear whether the high school news coverage of actual games was similar for boys and girls.

\section{Rationale for Study}

According to the National Federation of State High School Associations (NFHS 1969-2014), the number of girls participating in U.S. high school athletics surged from less than 300,000 before the passage of Title IX in 1972 to more than 3.2 million today. Across the U.S., basketball ranks first in terms of high school participation rates (NFHS 2013-2014). Participation statistics within the State of Ohio reflect the U.S. national trend of more girls signing up for high school sports generally and for the sport of basketball specifically. For example, the number of girls participating in Ohio high school basketball programs increased from 6,495 to 17,298 between 1971 and 2014 (NFHS 1969-2014). Today, the number of Ohio boys' and girls' high schools basketball programs is nearly identical (e.g., there were 809 boys' and 808 girls' programs in 2011; NFHS 2012-2013). Given the tremendous rise in participation rates and an overall increase in interest in girls' high school sports, we set out to investigate if local print media coverage of boys and girls' high school basketball games was equitable. We choose basketball because the sport is played by both genders and, as just noted, there are nearly even numbers of Ohio high schools offering the sport to boy and girl athletes.

In the present investigation, we examined the length of print coverage of boys' and girls' basketball games within two community newspapers. We selected two high schools located within 30 miles of our campus. This enabled us to conveniently visit local libraries, scour through their microfilm reserves, and collect data over the course of several days. Unlike the aforementioned studies, we counted the actual number of words used in each article and restricted our sample to only game coverage. Additionally, following the recommendation of Pedersen (2002a), we inspected multiple years' worth of coverage at each paper, with stories covering high school boys' and girls' basketball seasons ending within the 2001-2010 decade. We coded for a number of variables including where the game was played, the outcome of the game, whether a picture accompanied the article, and where on the sports page the article was placed. We predicted that articles about boys' games would be longer in length, be accompanied by more pictures, and begin more prominently (i.e., higher) on the sports page. 


\section{Sample Selection}

\section{MATERIALS \& METHOD}

We tabulated information across eight basketball seasons, four each from two high schools located in west-central Ohio: Lima Senior High School and Kenton High School. We selected seasons that ended within the 2001-2010 decade and tried to pick seasons where the win-loss record between the boys' and girls' teams were the least unbalanced. There was a total of $\mathrm{N}$ $=319$ boys' and girls' games across all eight basketball seasons sampled. Game coverage for each school appeared in their respective hometown newspapers: The Lima News (TLN) and the Kenton Times (KT). According to the 2010 U.S. Census, the population of Lima and Kenton, Ohio, was approximately 38,800 and 8,200 , respectively. In 2014, circulation rates were approximately 30,000 and 2,300 for TLN and the KT, respectively.

To locate articles, we searched microfiche holdings from each town's library. We scanned archived newspapers dated from one to four days after each game was played. For 11 games, we failed to find any coverage of the game, including one game where the likely issue covering the game was missing from the archives. For another eight games, coverage consisted of only a box score (i.e., only team scores and player statistics were listed with no narrative content). The total sample of games with narrative content was $\mathrm{N}$ $=300$.

\section{Procedure}

For each of the 300 games with narrative content, we made physical copies of the newspaper articles along with any accompanying picture(s). Two undergraduate research assistants inspected each article on at least two occasions and calculated values for all of the variables used in this investigation. If there were any discrepancies between our coders, another assistant independently tabulated variable values. Final data counts were reached by consensus following discussions.

\section{Variables}

Our main variable of interest was the number of words used to cover the games. We also recorded the number of pictures accompanying the article. We recorded the following dichotomous variables: gender; newspaper/team; gamelocation (homevs. away); game outcome (win vs. loss); narrative article or box score; whether the coverage of a boys' game and a girls' game appeared in the same issue of the paper; and, whether a picture was present along with the article. We also coded the placement of article based on where the story began on the newspaper page (i.e., top, middle, or bottom).

For consistency both within and across papers, we adopted the following rules for determining the number of words used in each article:

1. Excluded headlines and bylines from the word count because there were occasions when the coverage of a boys' and girls' game occurred under a single headline.

2. Excluded the location (e.g., city and/or state names), if used to geographically place the game before narrative content began, because some city names contained more than one word.

3. Counted school names (e.g., Lima Senior High School), nicknames (e.g., Fighting Irish), combinations of the two (e.g., Lima Senior High School Spartans), and conference names (e.g., Greater Buckeye Conference) as one word, regardless of the actual number of words included in these titles because some school's nicknames varied by gender (e.g., Wildcats vs. Wild Kittens).

4. Counted the article "the" as a separate word, even when it preceded school names or nicknames (e.g., "... the Lima Senior Spartans ...” counted as two words).

5. Counted hyphenated words or hyphenated numerical listings (e.g., "54-48”) as one word.

6. Counted the first and last name of a player as separate words. Middle names and initials, however, did not count when appearing with first and last names (e.g., both "Susan Ann Kasper" and "I. James Smith" counted as two words). We counted initials representing first or last names as a word (e.g., "I. Smith" counted as two words). Because we were concerned that the use of a middle name might be more common with a certain gender, we counted instances where first or last names consisted of two words (e.g., "Mary Ann" or "Van Dyke") as one word.

7. Counted dates (e.g., "December 4, 2006"), time references (e.g., "6:30 pm”), and rankings (e.g., "Number 1") as one word.

8. Counted articles and pronouns as individual words.

\section{Preliminary analysis}

\section{RESULTS}

Games with narrative coverage. We identified a total of 319 boys' and girls' basketball games across four seasons at two different area high schools. There were 11 instances where we did not find any newspaper 
coverage of the game within our four-days-after-thegame search criterion. Of these 11 games, nine of them were girls' games (seven from TLN; two from KT). News coverage of another eight games, all played by girls, consisted of only a box score with no narrative content (all in the TLN). Our primary analyses were based on 300 games with narrative coverage.

\section{Primary analyses}

Length of coverage. We examined the number of words used when covering a game in a 2 (gender: boys vs. girls) x 2 (location: home vs. away) x 2 (outcome: win vs. loss) factorial ANOVA for each of our schools. Because the data we extracted came from two different newspapers covering games across different sets of basketball seasons, we examined the coverage of boys' and girls' games separately by newspaper. We identified eight cases as potential outliers. Because the results were the same regardless of retaining or removing these cases, we present findings based on the entire data set.

Within TLN, we obtained a significant interaction between gender and location, $\mathrm{F}(1,136)=26.56$, $\mathrm{p}<$ .001 ; a main effect for location $\left(\mathrm{M}_{\text {home }}=298.70\right.$, SD $\left.=202.17 ; \mathrm{M}_{\text {away }}=169.97, \mathrm{SD}=184.37\right), \mathrm{F}(1,136)=$ $14.54, \mathrm{p}<.001$; and a main effect for gender $\left(\mathrm{M}_{\text {boys }}=\right.$ $\left.316.58, \mathrm{SD}=201.10 ; \mathrm{M}_{\text {girls }}=142.29, \mathrm{SD}=162.96\right)$, $\mathrm{F}(1,136)=30.35, \mathrm{p}<.001$. Figure 1 displays the interaction between gender and game location and shows that whereas boys received more coverage than girls for both home and away games, the coverage differential was most dramatic for home games (i.e., $\mathrm{M}_{\text {boysathome }}=435.21, \mathrm{SD}=125.81 ; \mathrm{M}_{\text {girls at home }}=120.82$, $\mathrm{SD}=131.70)$. Within TLN, we found a large effect for gender influencing the number of words used to cover the game (Cohen's $\mathrm{d}=.94$ ), and the point-biserial correlation between length of coverage and gender was $\mathrm{r}=.43, \mathrm{p}<.01$.

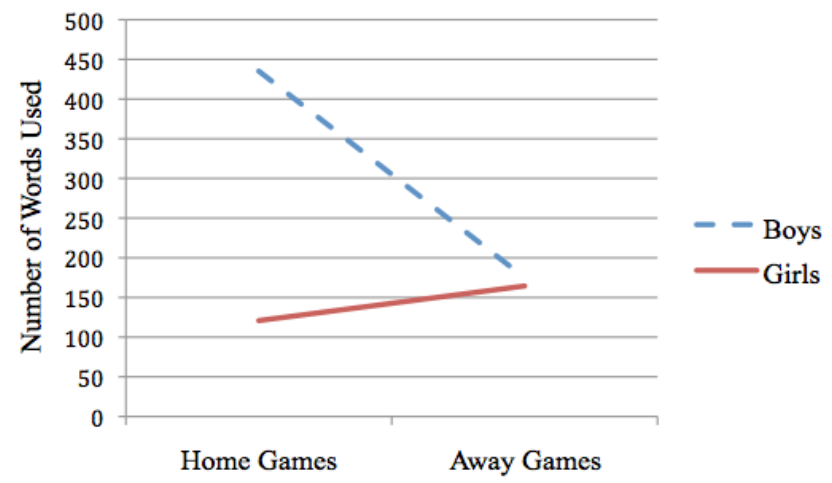

FIGURE 1. The number of words to cover boys' and girls' basketball games by game location, within TLN.
Within the KT, we obtained a significant interaction between gender and outcome, $\mathrm{F}(1,148)=7.48$, $\mathrm{p}<$ .005; a main effect for outcome $\left(\mathrm{M}_{\text {win }}=725.07\right.$, SD $\left.=235.80 ; \mathrm{M}_{\text {loss }}=546.94, \mathrm{SD}=312.68\right), \mathrm{F}(1,148)=$ 9.44, $\mathrm{p}<.005$; and a main effect for gender $\left(\mathrm{M}_{\text {boys }}=\right.$ 753.67, $\left.\mathrm{SD}=226.70 ; \mathrm{M}_{\text {girls }}=466.70, \mathrm{SD}=295.21\right)$, $\mathrm{F}(1,148)=27.79, \mathrm{p}<.001$. Figure 2 displays the interaction between gender and game outcome and shows that whereas boys received more coverage than girls for games won as well as games lost, the coverage differential was most dramatic for games lost (i.e., $M_{\text {boys }}$ and loss $=748.30, \mathrm{SD}=218.85 ; \mathrm{M}_{\text {girls and loss }}=392.32, \mathrm{SD}$ $=285.65)$. Within the KT, we found a very large effect for gender influencing the number of words used to cover the game (Cohen's $\mathrm{d}=1.10$ ), and the pointbiserial correlation between length of coverage and gender was $r=.48, p<.01$. Table 1 lists the average length of coverage by season for the boys' and girls' games at each school.

Given the overall number of cases and because of the fact that there was a reasonably similar number of boys' and girls' games analyzed for each school, the aforementioned ANOVA results are likely robust despite violations of normality and equal variances. Even after removing potential outliers, the distribution of the number of words was not normal for three of our four categories (Kolmolgorov-Smirnov values ranged from .14 to .28 , all $\mathrm{ps}<.001)$. Attempts to transform the data to render it normal (e.g., log transformations) failed. Furthermore, Levene's test was significant for both schools indicating that the variance associated with the amount of coverage was unequal between the boys and girls games.

In order to counter concerns about violating ANOVA assumptions, we also conducted non-parametric tests on the length of coverage as a function of our primary variable of interest, gender, at both schools. Results

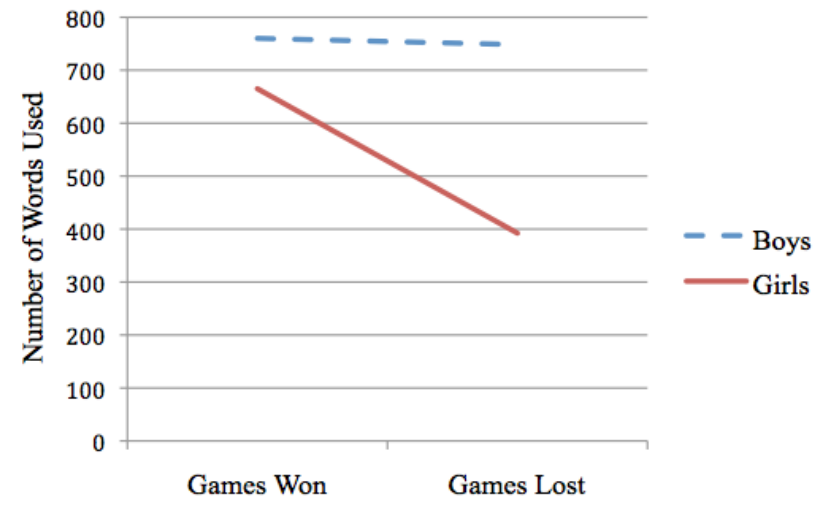

FIGURE 2. The number of words to cover boys' and girls' basketball games by game outcome, within KT. 
Table 1

Average and Median Number of Words Used in the Newspaper Coverage of Boys' and Girls' Games by Paper

\begin{tabular}{|c|c|c|c|c|c|c|}
\hline Paper & Season & Gender & Record & Mean & (SD) & Median \\
\hline \multicolumn{7}{|c|}{ Kenton Times (KT) } \\
\hline & 2000-2001 & $\begin{array}{l}\text { Boys } \\
\text { Girls }\end{array}$ & $\begin{array}{l}14-6 \\
11-8\end{array}$ & $\begin{array}{l}704.60 \\
616.68\end{array}$ & $\begin{array}{l}(95.38) \\
(103.44)\end{array}$ & $\begin{array}{l}694.00 \\
623.00\end{array}$ \\
\hline & 2003-2004 & $\begin{array}{l}\text { Boys } \\
\text { Girls }\end{array}$ & $\begin{array}{l}0-20 \\
6-14\end{array}$ & $\begin{array}{l}709.85 \\
588.60\end{array}$ & $\begin{array}{l}(197.48) \\
(379.34)\end{array}$ & $\begin{array}{l}804.50 \\
548.50\end{array}$ \\
\hline & $2007-2008$ & $\begin{array}{l}\text { Boys } \\
\text { Girls }\end{array}$ & $\begin{array}{c}16-4 \\
2-18\end{array}$ & $\begin{array}{l}895.85 \\
323.00\end{array}$ & $\begin{array}{l}(290.93) \\
(268.39)\end{array}$ & $\begin{array}{l}933.00 \\
167.50\end{array}$ \\
\hline & $2009-2010$ & $\begin{array}{l}\text { Boys } \\
\text { Girls }\end{array}$ & $\begin{array}{l}6-13 \\
2-16\end{array}$ & $\begin{array}{l}616.53 \\
332.61\end{array}$ & $\begin{array}{l}(189.89) \\
(225.81)\end{array}$ & $\begin{array}{l}624.00 \\
282.00\end{array}$ \\
\hline & Totals & $\begin{array}{l}\text { Boys } \\
\text { Girls }\end{array}$ & $\begin{array}{l}36-43 \\
21-56\end{array}$ & $\begin{array}{l}753.67 \\
466.70\end{array}$ & $\begin{array}{l}(226.70) \\
(295.21)\end{array}$ & $\begin{array}{l}747.00 \\
471.00\end{array}$ \\
\hline
\end{tabular}

The Lima News (TLN)

\begin{tabular}{|c|c|c|c|c|c|}
\hline $2002-2003$ & $\begin{array}{l}\text { Boys } \\
\text { Girls }\end{array}$ & $\begin{array}{l}9-11 \\
6-12\end{array}$ & $\begin{array}{l}268.60 \\
78.67\end{array}$ & $\begin{array}{l}(175.30) \\
(123.56)\end{array}$ & $\begin{array}{l}217.00 \\
30.00\end{array}$ \\
\hline 2003-2004 & $\begin{array}{l}\text { Boys } \\
\text { Girls }\end{array}$ & $\begin{array}{l}16-4 \\
2-10\end{array}$ & $\begin{array}{c}389.10 \\
118.50\end{array}$ & $\begin{array}{l}(219.25) \\
(159.86)\end{array}$ & $\begin{array}{l}490.50 \\
61.50\end{array}$ \\
\hline 2006-2007 & $\begin{array}{l}\text { Boys } \\
\text { Girls }\end{array}$ & $\begin{array}{l}6-13 \\
2-14\end{array}$ & $\begin{array}{c}241.74 \\
124.69\end{array}$ & $\begin{array}{l}(185.03) \\
(121.98)\end{array}$ & $\begin{array}{l}177.00 \\
87.50\end{array}$ \\
\hline $2009-2010$ & $\begin{array}{l}\text { Boys } \\
\text { Girls }\end{array}$ & $\begin{array}{l}11-9 \\
11-8\end{array}$ & $\begin{array}{l}363.15 \\
232.42\end{array}$ & $\begin{array}{l}(197.35) \\
(196.76)\end{array}$ & $\begin{array}{l}438.00 \\
214.00\end{array}$ \\
\hline Totals & $\begin{array}{l}\text { Boys } \\
\text { Girls }\end{array}$ & $\begin{array}{l}42-37 \\
21-44\end{array}$ & $\begin{array}{l}316.58 \\
142.29\end{array}$ & $\begin{array}{l}(201.10) \\
(162.96)\end{array}$ & $\begin{array}{l}375.00 \\
60.00\end{array}$ \\
\hline
\end{tabular}

Totals (both papers)

$\begin{array}{lllll}\text { Boys } & 78-80 & 535.13 & (306.09) & 535.50 \\ \text { Girls } & 42-100 & 318.20 & (292.12) & 179.00\end{array}$


from Mann-Whitney $U$ tests showed that TLN provided more lengthy coverage of boys' games than girls' games (mean ranks $=91.15,49.84$, respectively; $\mathrm{U}=1094.50, \mathrm{Z}=5.91, \mathrm{p}<.001)$. Within the KT, the same pattern emerged (mean ranks $=99.89$, 56.56, respectively; $\mathrm{U}=1,352.00, \mathrm{p}<.001)$.

Additional tests on specific seasons. Given that greater press coverage in the KT was associated with games won versus games lost and that a similar, albeit non-significant, pattern was found in TLN $\left(\mathrm{M}_{\text {win }}=\right.$ $297.43, \mathrm{SD}=213.97 ; \mathrm{M}_{\text {loss }}=191.62, \mathrm{SD}=183.79$ ), we wanted to more closely examine the possibility that greater news coverage of boys' games might reflect more successful seasons. To further explore this possibility, we conducted separate one-way ANOVAs on the two instances where the girls' record was either clearly superior to that of the boys (i.e., the girls won 30 percent $(6 / 20)$ of their games and the boys won none of their games during the 2003-2004 season at Kenton High School) or was at least statistically better in terms of the overall winning percentage (i.e., the winning percentage was slightly higher for the girls (58 percent; 11/19) versus the boys (55 percent; 11/20) during the 2009-2010 season at Lima Senior High School). Results showed that the boys received more coverage than the girls during both of these seasons, Fs $>4.29$, ps $<.05$.

We also conducted non-parametric tests on the news coverage by gender for these two seasons. Results showed that TLN provided greater press coverage to boys' games (mean rank $=24.63$; median $=438.00)$ than girls' games (mean rank $=15.13$; median $=$ 214.00), $U=97.50, Z=2.60, p<.005$ (one tailed test). Similarly, the KT provided more lengthy press coverage to the boys' games (mean rank $=23.70$; median $=804.50)$ than girls' games (mean rank = 17.30; median $=548.50), U=136.00, Z=1.73, p=$ .04 (one tailed test).

Trends over time. For each team, we performed two linear trend analyses to explore whether the length of articles for the boys' and girls' teams changed over the course of the four seasons sampled. Within TLN, there was no linear change in the average length of coverage of boys' games across the four seasons, $t(75)=-0.70$, $p$ $=.49$. Within TLN, there was a positive linear change in the average length of coverage across the four girls' basketball seasons, $\mathrm{t}(37)=-2.74, \mathrm{p}<.01$ (Levene's test of unequal variances was positive $(\mathrm{F}=5.31, \mathrm{p}=.003)$ so the degrees of freedom were adjusted accordingly). Within the KT, there was no linear change in the average length of coverage across the four boys' seasons, $\mathrm{t}(75)$ $=-0.77, \mathrm{p}=.45$. Within the KT, there was a negative linear change in the average length of coverage across the girls' four basketball seasons, $\mathrm{t}(39)=-5.50, \mathrm{p}<$ .001 (again, Levene's test was positive $(\mathrm{F}=14.72$, $\mathrm{p}<$ .001 ) so the degrees of freedom were adjusted).

Same print day. To address the possibility that the shorter length of coverage for girls' games might be due to a different weekday when their game coverage typically appeared in the paper, we examined those occurrences when the coverage of girls' and boys' games appeared in the same issue of the paper. There were 15 such instances; however, on two occasions, the girls' game was covered only by a box score. Across the nine instances where both boys' and girls' games had narrative coverage in the same issue of TLN, boys $(\mathrm{M}=247.78, \mathrm{SD}=185.78)$ received greater coverage than girls $(\mathrm{M}=49.89, \mathrm{SD}=22.01), \mathrm{F}(1,16)=9.84$, $\mathrm{p}=.003$ (one tail test). Across the four instances of same day coverage in the KT, boys $(\mathrm{M}=897.00, \mathrm{SD}$ $=200.11)$ received greater coverage than girls $(\mathrm{M}=$ $380.00, \mathrm{SD}=387.10$ ) $, \mathrm{F}(1,6)=5.63, \mathrm{p}=.028$ (one tail test).

Using non-parametric tests on the nine instances where TLN covered both boys' and girls' games in the same issue of the paper, we found that the length of coverage was greater for boys' games (mean rank $=13.39 ;$ median $=164.00)$ than girls' games (mean rank $=5.61 ;$ median $=34.00), U=5.50, Z=3.09, p$ $=.001$. Across the 4 pairs of games that were covered in the same issue of the KT, the length of coverage tended to be greater for boys' games (mean rank = 5.75; median $=827.00$ ) than girls' games (mean rank = 3.25; median $=270.50), \mathrm{U}=3.00, \mathrm{Z}=1.44, \mathrm{p}=$ .10 (one tailed test).

Presence of photograph. In TLN, a picture accompanied the coverage of boys' basketball games 41 out of 79 games (52 percent); whereas a picture accompanied the coverage of girls' games 28 out of 65 games ( 43 percent), $\mathrm{X}^{2}(1 ; \mathrm{N}=144)=1.11, \mathrm{p}=.15$ (one tail). If the eight games with only box scores were included, the frequency of a picture accompanying a girls' game dropped to 28 out of 73 (38 percent) making the frequency differential statistically significant, $\mathrm{X}^{2}(1$; $\mathrm{N}=152$ ) $=2.81, \mathrm{p}<.05$ (one tail). Whereas the KT usually placed pictures alongside game articles, pictures were more likely to accompany boys' games (72/79; 91 percent) relative to girls' games $(62 / 77 ; 80$ percent $)$, $\mathrm{X}^{2}(1 ; \mathrm{N}=156)=3.63, \mathrm{p}<.05$.

Next, we examined instances when game coverage 
included a picture and tabulated the number of pictures by gender. Within TLN, boys' games averaged more pictures $(\mathrm{M}=1.59$; $\mathrm{SD}=0.92)$ than girls' games $(\mathrm{M}=$ 1.29; $\mathrm{SD}=0.54), \mathrm{t}(65.55)=1.70, \mathrm{p}<.05$ (one tailed test). The average number of pictures per game in the KT was equivalent across boys' and girls' games (both $\mathrm{Ms}=1.32$; both SDs $=0.47), \mathrm{t}(132)=0.38, \mathrm{p}=.48$ (one tail test).

Placement of article. Lastly, we examined the placement of the article and whether news coverage began at the top, middle or bottom of the page. Within TLN and the KT, placement did not significantly differ by gender. Specifically, within TLN, articles featuring games played by boys, relative to girls, began at the top (35.4 percent v. 30.8 percent), middle ( 43.0 percent v. 53.8 percent), and bottom (21.5 percent v. 15.4 percent) of the page at a similar statistical frequency, $\mathrm{X}^{2}(2 ; \mathrm{N}=144)=1.82, \mathrm{p}=.40$. Within the KT, articles featuring games played by boys, relative to girls, began at the top (87.3 percent v. 76.6 percent), middle (6.3 percent v. 13.0 percent), and bottom (6.3 percent v. 10.4 percent) of the page at a similar statistical frequency, $\mathrm{X}^{2}(2 ; \mathrm{N}=156)=3.11, \mathrm{p}=.21$.

\section{DISCUSSION}

Within two samples of west-central Ohio newspapers' coverage of high school basketball games, we found clear evidence that boys received more print media attention than girls. Regardless of whether we analyzed the average number of words used to cover the games or the median length of coverage, results were consistent in showing that girls' basketball games received far less extensive coverage than boys' games. Indeed, our findings were impressive in that boys typically received double to triple the coverage allotted to girls. Across two newspapers' coverage of four years of basketball seasons ending within the 2001-2010 decade, a total of 65.2 percent of the game coverage was dedicated to boys' teams.

Within one of our papers, home games garnered more coverage than away games. Still, boys received more lengthy coverage regardless of where the game was played. Within the other paper sampled, games where the indexed team won secured greater coverage than games that were lost; yet again, boys received more coverage regardless of the outcome of the game. Within Ohio, it is common for boys and girls to play most of their games on different days along with a few games played on the same day. If girls' games are regularly scheduled on a particular day of the week that is different from when the boys play their games, then the subsequent news coverage of girls' and boys' games would likely appear in different editions of the paper. One might conjecture that the relative lack of coverage of girls' games, then, might be due to when the girls' game coverage appears within a given newspaper (e.g., perhaps an advertising section, special feature, or weekly coverage of a local event regularly appears on the same day that the girls' games are also reported). When we restricted our analyses to coverage of only those boys' and girls' games that were covered in the same issue of the paper, we found that boys received more extensive coverage than girls. This latter contrast is noteworthy because it mitigates any supposition that girls receive less coverage because of the day of the week when their games are covered might be "busy news days." Perhaps most telling is that this pattern of preferential treatment of boys' games persisted during the two seasons when the girls finished the season with a better winning percentage than the boys. Therefore, our findings regarding the differential length of media coverage cannot be explained by team success or rate of winning. Instead, our results are most likely explained by gender bias and the tendency for local media to preferentially focus on boys' sports.

Within both papers, we found that coverage of boys' basketball games were more likely to include a photograph. Furthermore, in one of our papers, boys were more likely to have more than one picture accompanying their press coverage. Pedersen (2002b) similarly reported that fewer photographs accompany stories on girls' sports. Whiteside and RightlerMcDaniels (2013) found no gender differences in terms of article placement after coding for the section of the paper that the article appeared in (e.g., front page versus sports page). In contrast, because nearly all of our articles were in the sports section, we examined placement in terms of where on the sports' page the article began (e.g., top, middle, or bottom). Although we did not find statistically significant differences, the trend across both papers was for the coverage of boys' games to start at a higher, more prominent place on the page.

Unlike many studies examining quality of news coverage at the professional ranks, Huffman et al. (2004) did not find qualitative differences in print and broadcast coverage of men and women's sports at the collegiate level. It is worth noting that they included feature stories in their sample and did not restrict their analyses to articles of actual game coverage. More gender 
equitable news coverage (in terms of article length, number of quotes, picture quality, etc.) is arguably more likely to be found when the focus of the story is on an individual athlete compared to team coverage across an entire season. Indeed, special features like "athlete of the week" columns often have a preset length and format that is followed regardless of the gender of the honoree. A unique feature of our study is that we restricted our analyses to game coverage, and, unlike other investigations of high school sports coverage taking samples of articles published over the course of a couple of weeks or months, we examined coverage of all games played across eight basketball seasons.

We believe that we are among the first to measure article length of games by counting the number of words used in the media coverage. In contrast, Pedersen (2002a) measured the length of columns in inches and Whiteside and Rightler-McDaniels (2013) counted the number of paragraphs. We argue that an actual word count approach is likely to be more precise because column width and the number of words within a given paragraph may vary both within and across articles. Regardless of how length of media coverage is measured, and despite geographical, sampling, and methodological differences, our findings are remarkably consistent with those previously reported. Specifically, in sampling newspaper coverage of basketball games in the southern region of the US, Whiteside and RightlerMcDaniels (2013) found that boys' received 63 percent of the coverage. Examining a broad array of different sports covered by Florida newspapers, Pedersen (2002a) found that 58.3 percent $(1,045 / 1,792)$ of the articles were about male athletes. Excluding 184 stories featuring "other athletic events and personnel" (e.g., stories about booster clubs, athletic directors), we recalculated this statistic and found that 64.9 percent of the stories covered by Pedersen (2002a) featured boy athletes or boys' teams. Similarly, in the present investigation, we found that boys received 65 percent of actual game coverage within two Ohio newspapers spanning eight different basketball seasons.

The production and consumption of sports media is complex and may reflect numerous variables including the attitudes, values, and perceptions of what is "natural" for boys and girls, equal access initiatives, and racial stereotypes (Hardin and Whiteside 2008). Pedersen (2002b) argued that mass media and sports are symbiotically linked and represent two of the most prominent hegemonic social institutions today (see also Sage 1998). The belief that sports are "naturally male" may represent a type of hegemonic masculinity whereby sports reflect power, toughness, and social hierarchy (Connell 2005), leading to the exclusion of women from sports fan communities (Esmonde et al. 2015). Intertwined with the belief that males are naturally more athletic are ideas of racial differences regarding "natural" athleticism, the relevance of hard work to athletic success, and the likelihood of moral lapses during competition (Hardin and Whiteside 2008). In their review of more than 500 print and online articles covering the 2004 NCAA basketball tournament, Kian et al. (2008) concluded that media coverage continues to marginalize women's sports and female athletes: “... despite the improved visibility and profile of women's collegiate basketball, the newspaper and online articles ... consistently constructed narratives that reinforced a hierarchal gender order in sport. The contents of these narratives praised women but also trivialized them by regularly comparing female players unfavorably with male players, discussing the men's tournament within women's sports coverage, and noting the importance of fathers to female players' successes, while rarely presenting narratives that framed the opposite of those concepts in articles on men's basketball."

The social construction of gender determines what sports and activities are acceptable for girls and influences our attitudes and values about the role of sports in the development of girls' personal and interpersonal skills (Hall 2008). Sports participation rates for both sexes decline during adolescence, however, girls are more than six times more likely than boys to drop out of sports during this developmental time period (Lopiano 2002). Support from family, schools, and the community all likely play a role in encouraging (or discouraging) girls from playing sports . According to Ruth Hall (2008), a diminished or a lack of parental support during adolescence may explain why girls drop out of sports at a much higher rate than boys: "The absence of parental support is expressed in a variety of ways: showing an overt lack of interest (for example, not attending her games), stating that she will outgrow her interest in sports, offering support only for participation in cheerleading or other "feminine activities," or being unwilling (rather than unable) to purchase the proper equipment." School officials play a critical role guaranteeing that girls have fair and equitable practice times, balancing the publicity of boys' and girls' sports programs, and ensuring that the quality of equipment, uniforms, and other resources including expenditures for coaches' pay are equally 
distributed across boys' and girls' teams. Community and area businesses, including local news outlets, also play an important role in encouraging and supporting youth sports programming. We agree with Lauterer (2006) that "nowhere is the reciprocal relationship between the paper and community more strongly evident than in the arena of sports."

In addition to a decline in sports participation during the teen years, self-esteem drops among girls during adolescence (Basow and Rubin 1999; Gilligan 1990); however, the magnitude of the decline in self-esteem among adolescent girls is likely less than popularly believed (Hyde 2014). Whatever the magnitude, this phenomenon of declining self-esteem undoubtedly reflects a complex interaction of multiple variables, including biological, social, cultural, parental, and interpersonal influences. Self-esteem may reflect the real or perceived belief that others value and respect a person's activities and accomplishments. The amount of public attention given to an individual, or by extension, to their school's athletic team, may very well contribute to an overall sense of purpose, pride, and self-worth. How much of the precipitous drop in sports participation among adolescent girls might be attributable to deficient newspaper coverage of their sporting events? Does a lack of media coverage negatively affect self-esteem?

We certainly do not suggest that the length of media coverage of youth sporting events determines athletic participation rates or the self-esteem of female athletes. However, among the various social and community variables that might affect both sports participation rates and girls' sense of pride regarding their athleticism, providing more equitable news coverage of high school sports seems to be an actionable goal. We agree with the view expressed by Pedersen (2002a), "Such unfair coverage establishes barriers to participation by females, fails to provide role models, hinders the advancement of females in sports, influences the recognition females receive for their participation, and impacts the level of fulfillment that females can obtain through their participation."

Perhaps, as society continues to evolve and more attention is paid to the unequal treatment of girls' and women's sports, future research will show gradual improvements in both the quantity and quality of news coverage of female athletes across all levels of sports competition. While we were encouraged by a positive trend for increased coverage of girls' games across time within one of the papers that we studied, any optimism that things may be gradually improving was undercut by the exact opposite pattern in the other paper. Merely inspecting the different lengths of coverage by gender during the very last seasons that we sampled (i.e., in 2010) within each of the papers shows the persistence of inequitable coverage of high school sports based on gender.

Clearly, many gains have been made since the dawn of Title IX. Today, contemporary sports journalists hold less negative views of Title IX than previous generations of media workers (Hardin 2005); yet, misperceptions about the impact of the legislation abound. Many mistakenly continue to believe that increases in the number of women's sports at the collegiate level necessarily means a cut or reduction in the corresponding number of men's teams (see Title IX at 40 White Paper report, Women's Sports Foundation 2013). Whereas Title IX was a critically important first step, much more work needs to be done to fully realize the goal of equal access and equal treatment of male and female athletes within U.S. high schools and colleges. Huffman et al. (2004) summarized the progress as follows: "Title IX guarantees women equal access to sports participation at institutions receiving federal dollars. It does not guarantee that participation will be recognized by media outlets, either at the institution or beyond."

The U.S. Department of Education's Office for Civil Rights enforces Title IX compliance across institutions receiving federal assistance. Title IX does not only add ress inequalities within sports, it prohibits sex-based discrimination in the following areas: "recruitment, admissions, and counseling; financial assistance; athletics; sex-based harassment; treatment of pregnant and parenting students; discipline; singlesex education; and employment" (OCR 2015). While commemorating 40 years of progress attributed to Title IX, President Obama reaffirmed his commitment to further advancing the goals of equal opportunity and gender equality, and he promised to bolster governmental efforts to create and maintain educational environments free from sexual discrimination and sexual violence. The President directed numerous federal agencies to develop common guidelines and best practices for Title IX compliance in order to reach these goals (White House Press Release 2012).

\section{LIMITATIONS AND CONCLUDING REMARKS}

A clear limitation of our study is that we restricted 
our examination to article length, along with a few other objective variables such as the presence of a photograph and article placement, without attempting to analyze the narrative content within the stories. Other researchers have conducted content analyses. For example, Carty (2005) discussed media portrayals of female athletes and how commercials and print ads reflect historical and contemporary constructions of femininity. Other scholars have noted that female athletes participating in team contact sports often face questions about their femininity, heterosexuality and competitiveness (Cahn 1994; Griffin 1998). Whiteside and Rightler-McDaniels' (2013) content analysis of high school sports coverage of boys and girls' basketball games revealed that stories about boys were more likely to reference physical size and use war metaphors, and less likely to reference emotions or include language suggesting mental weakness. Because more media coverage of girl and women athletes doesn't necessarily equate to better media coverage (Bernstein 2002), future studies should examine both the quantity and the quality of high school sports coverage across a variety of sports played by girls and boys (e.g., tennis, golf, track, cross country, basketball, baseball/softball).

Our findings are limited by our sample of only two community newspapers in one geographic region within the state of Ohio. Future investigations should not only sample a greater number of newspapers but also consider possible regional differences to determine if the pattern of gender bias in the coverage of high school sports parallels that of college sports. In addition to actual game coverage, future work should examine the role of gender in feature articles, season previews, and special reports focusing on high school athletes. With increased popularity of online media coverage of sports, additional explorations should be conducted on the e-coverage of young athletes as well.

We conclude by suggesting that the implications of our findings, and those of other studies showing that coverage of female sports pales in comparison to that of males, go beyond principles of equality and fairness and invite a much wider discussion about gender transcendence, the importance of inclusiveness within our society, and, most importantly, the value of recognizing effort and achievement among young female athletes. We hope that our study leads to greater awareness of gender bias in newspaper coverage of high school sports and inspires more research on the topic of gender equity in sports media at the interscholastic level. We also hope that this paper, in some small way, enlightens sports writers and newspaper editors, school officials dealing with the press, and other decision-makers within schools and the media about the importance of female athletics by accentuating the fact that subtle and sometimes not so subtle messages that girls' sports are less relevant than boys are made at the peril of social justice and individual well being.

\section{LITERATURE CITED}

Basow SA, Rubin LR. 1999. Gender influences on adolescent development. In Johnson N, Roberts MC, Worrell J, editors. Beyond appearance: new look at adolescent girls. Washington, DC: American Psychological Association; p. 25-52. doi: http://dx.doi.org/10.1037/10325-001

Bissell K, Birchall K. 2008. Through the hoop: how sports participation displaces media use and is related to body self-esteem in competitive female athletes. J Sports Media. 3(2): 25-59.

Bunker LK. 1988. Life-long benefits of youth sport participation for girls and women. Paper presented at: Sport Psychology Conference; University of Virginia, Charlottesville, VA.

Bernstein A. 2002. 'Is it time for a victory lap?' Changes in the media coverage of women in sport. Int Rev Sociol Sport. 37(3/4): 415-428. doi: 10.1177/101269020203700301

Cahn SK. 1994. Coming on strong: gender and sexuality in twentieth century women's sport. New York: The Free Press.

Calia GN. 1993. A historical analysis of the impact of Title IX on student media presentation of women athletes [dissertation]. [Bronx, (NY)]: Fordham University.

Carty V. 2005. Textual portrayals of female athletes: liberation or nuanced forms of patriarchy? Frontiers: J Women Stud. 26(2): 132-155.

Connell RW. 2005. Masculinities [2 ${ }^{\text {nd }}$ ed]. Berkeley, CA: University of California Press.

Cooky C, Wachs FL, Messner M, Dworkin SL. 2010. It's not about the game: Don Imus, race, class, gender and sexuality in contemporary media. Sociol Sport J. 27(2): 139-159.

Currie A. 2010. Sport and eating disorders: Understanding and managing the risks. Asian J Sports Med. 1(2): 63-68. doi: 10.5812/asjsm.34864

Dever BV, Schulenberg JE, Dworkin JB, O’Malley PM, Kloska DD, \& Bachman JG. 2013. Predicting risk-taking with and without substance use: the effects of parental monitoring, school bonding, and sports participation. Prev Sci. 13(6): 605-615. doi: 10.1007/s11121-012-0288-z

Dodge TL, Jaccard JJ. 2006. The effect of high school sports participation on the use of performance enhancing substances in young adulthood. J Adolescent Health. 39(3): 367-373. doi: http://dx.doi.org/10.1016/j.jadohealth.2005.12.025.

Eastman ST, Billings AC. 2000. Sportscasting and sports reporting: the power of gender bias. J Sport Soc Issues. 24(2): 192-213. doi: http://dx.doi.org/10.1177/0193723500242006.

Esmonde K, Cooky C, Andrews DL. 2015. "It's supposed to be about the love of the game, not the love of Aaron Rogers' eye": challenging the exclusions of women's sports fans. Sociol Sport J. 32(1): 22-48.

Gilligan C. 1990. Making Connections: the Relational World of Adolescent Girls at the Emma Willard School. Cambridge, MA: Harvard University Press.

Godoy-Pressland A. 2014. 'Nothing to report': a semi-longitudinal investigation of the print media coverage of sportswomen in 
British Sunday newspapers. Media Cult Soc. 36(5): 595-609.

Griffin P. 1998. Strong women, deep closets: lesbians and homophobia in women's sport. Champaign, IL: Human Kinetics.

Hall RL. 1998. Softly strong: African American women's use of exercise in therapy. Psychother Patient,. 10(3/4): 81-100. doi: 10.1300/J358v10n03_08

Hall RL. 2008. Sweating it out: the good news and bad news about women in sport. In Chrisler JC,Golden C, Rozee $\mathrm{PD}$, editors. Lectures on the psychology of women [ $4^{\text {th }} \mathrm{ed}$ ]. Boston, MA: McGraw Hill; p. 96-115.

Hardin M. 2005. Stopped at the gate: women's sports, "reader interest," and decision making by editors. J Mass Commun Q. 82(1): 62-77.

Hardin M, Corrigan TF. 2008. Media and the business of high school sports: a case for closer scrutiny. J Sports Media. 3(2): 89-94. doi: 10.1353/jsm.0.0023

Hardin M, Whiteside E. 2008. Maybe it's not a "generational thing": values and beliefs of aspiring sports journalists about race and gender. Media Report Women. 36(2): 8-16.

Huffman S, Tuggle CA, Rosengard DS. 2004. How campus media cover sports: the gender-equality issue, one generation later. Mass Commun Soc. 7(4): 475-489.

Hyde JS. 2014. Gender similarities and differences. Annu Rev Psych. 65(1): 373-398. doi: 10.1146/annurevpsych-010213-115057

[IOC] International Olympic Committee. 2014. Olympic Charter. Lausanne, Switzerland: International Olympic Committee.

Kian EM, Vincent J, Mondello M. 2008. Masculine hegemonic hoops: an analysis of media coverage of March Madness. Soc Sport J. 25(2): 223-242.

Keathley K, Himelein MJ, Srigley G. 2013. Youth soccer participation and withdrawal: gender similarities and differences. J Sport Behav. 36(2): 171-188.

Lauterer J. 2006. Community journalism: relentlessly local. Chapel Hill, NC: The University of North Carolina Press.

Le Menestrel S, Perkins DF. 2007. An overview of how sports, out-of-school time, and youth well-being can and do intersect. New Dir Youth Dev. 2007(115): 13-25.

Lopiano D. 2002. Gender equity in sports: whose responsibility is it? New York: Women's Sports Foundation.

[NFHS] National Federation of State High School Associations. 1969-2014 high school athletics participation survey results. [accessed 7 Apr. 2016]. http://www.nfhs.org/ ParticipationStatistics/ParticipationStatistics

[NFHS] National Federation of State High School Associations. 2012-2013 high school athletics participation survey results. [accessed 13 Feb 2015]. http://www.nfhs.org/ ParticipationStatistics/ParticipationStatistics.

[NFHS] National Federation of State High School Associations. 2013-2014 high school athletics participation survey results. [accessed 13 Feb 2015]. http://www.nfhs.org/ ParticipationStatistics/ParticipationStatistics.

[OCR] Office of Civil Rights (US Department of Education). Title IX and sex discrimination. [accessed 9 Apr 2016]. http://www2.ed.gov/about/offices/list/ocr/docs/tix_dis.html.

Pedersen PM. 2002a. Investigating interscholastic equity on the sports page: a content analysis of high school athletics newspaper articles. Soc Sport J. 19(4): 419-432.

Pedersen PM. 2002b. Examining equity in newspaper photographs: a content analysis of the print media photographic coverage of interscholastic athletics. Int Rev Sociol Sport. 37(3/4): 303-318. doi: 10.1177/1012690202037004895

Robinson J, Bradley-Doppes P, Neinas CM, Thelin, JR, Plonsky CA, Messner MA. 2002. Gender equity in college sports: 6 views. Chron Higher Ed. 49(15): B7-11.

Sage G. 1998. Power and ideology in American Sport: a critical perspective [ $2^{\text {nd }}$ ed]. Champaign, IL: Human Kinetics.

Smolak L, Murnen SK, Ruble AE. 2000. Female athletes and eating problems; a meta-analysis. Int J Eat Dis. 27(4):371-380. doi: 10.1002/(SICI) 1098-108X(200005)27:4<371::AIDEAT1>3.0.CO;2-Y.

Stevenson B. 2010. Beyond the classroom: using Title IX to measure the return to high school sports. Rev Econ Stat. 92(2): 284-301. doi: 10.1162/rest.2010.11623.

Taliaferro LA, Rienzo BA, Donovan KA. 2010. Relationships between youth sport participation and selected health risk behaviors form 1999 to 2007. J School Health. 80(8):399-410.

Wenner LA. 2015. Assessing the sociology of sport: on the mediasport interpellation and commodity narratives. Int Rev Sociol Sport. 50(4/5): 628-633. doi: 10.1177/1012690214560832.

White House Press Release. 2012. Obama administration commemorates 40 years of increasing equality and opportunity for women in education. [accessed 9 Apr 2016]. https:// www.whitehouse.gov/the-press-office/2012/06/20/obamaadministration-commemorates-40-years-increasing-equalityand-oppor.

WhitesideE, Rightler-McDaniels JL. 2013. Moving toward parity? Dominant gender ideology versus community journalism in high school basketball coverage. Mass Commun Soc. 16: 808-828. doi: 10.1080/15205436.2013.778998.

Women's Sports Foundation. 2009. Women's sports \& fitness facts and statistics [accessed 14 Feb 2015]. http://www. womenssportsfoundation.org/home/research/articles-andreports/athletes/womens-sports-facts.

Women's Sports Foundation. 2013. Proceedings of the Title IX at 40 conference: progress and promise, equity for all. [accessed 5 May 2014]. https://www.womenssportsfoundation.org/ home/research/articles-and-reports/equity-issues/progressand-promise-title-ix-at- 40 